\title{
The Influence of Dot Gain Mid Tone SPREAd ON PRINT QUALITY
}

\author{
ZJAKIC, I.; MiLCIC, D. \& BOLANCA, S.
}

Abstract: Through the development and the market organization, the development of electronics, robotics and technology the new standards of the printing quality and the production of the printed products have been set. As the printing quality is one of the most important factors which define the final quality of the printed products the researches in science lead to conclusion that it was necessary to satisfy the quality which had less and less permitted tolerance of quality deviations. The quality of the printed product is influenced by a series of factors which, depending on the conditions, can be or cannot be controlled during the printing of the production. Because of that the aim of each graphic production is to control and standardize the mentioned parameters according to the newest standards. Researches in this paper were performed on prints printed in real graphic production by caclulating mid tone spread. It was confirmed in the performed researches that the printing quality is variable depending on the quantity of prints. The mentioned oscillation of the printing quality is mostly seen in the dot gain which is in the researched conditions dependent on the optical dot gain.

Key words: Mid Tone Spread, Graphic Quality, Dot Gain, Ink, Density
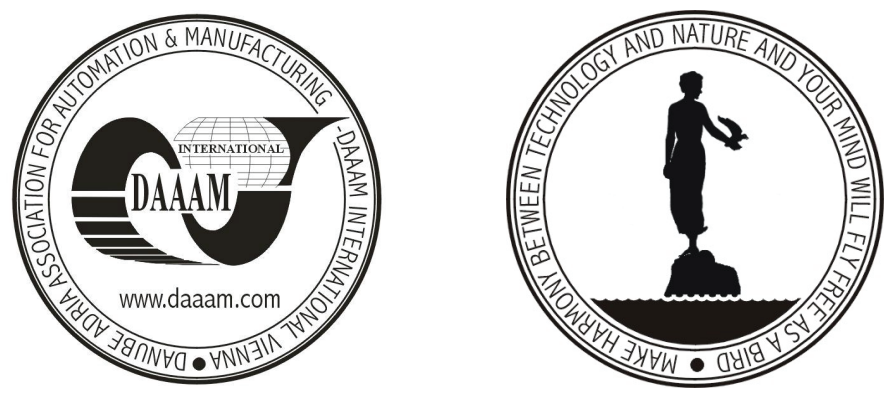

Authors' data: PhD. Ass. Prof. Zjakic I.[gor], PhD. Prof. Milcic D.[iana], PhD. Prof. Bolanca S.[tanislav], Faculty of Graphic Arts Zagreb, Croatia, zjakic@grf.hr , diana.milcic@grf.hr, sbolanca@grf.hr

This Publication has to be referred as: Zjakic, I.; Milcic, D. \& Bolanca S. (2006). The Influence of Dot Gain Mid Tone Spread on Print Quality, Chapter 54 in DAAAM International Scientific Book 2006, B. Katalinic (Ed.), Published by DAAAM International, ISBN 3-901509-47-X, ISSN 1726-9687, Vienna, Austria DOI: $10.2507 /$ daaam.scibook.2006.54 